\title{
s Jornais e os Mundos Paralelos
}

Galeno de Freitas $\boldsymbol{I}$

Usava-se até pouco tempo um método estatístico que enfatizava a forma e o conteúdo das matérias apresentadas por um jornal determinado. A crescente importância da sociologia no cosmos científico, e sua utilização pela "mass media" deslocava parte da ênfase para o público dos jornais. Assim, ao invés de examinar apenas o veículo emissor, dialetizava-se a análise tomando em consideração o público do jornal, isto é, o receptor.

Um jornal como O Globo, do Rio de Janeiro, é destinado a um público bastante específico e definido -a burguesia e camadas da pequena burguesia. Malgrado o amorfismo destas secções da sociedade, é preciso notar que elas têm certos objetivos e aspirações comuns. Uma parcela dessa classe, bem típica, a dona de casa burguesa, encontra n'O Globo considerável quantidade de temas que lhe toca diretamente o que se convencionou chamar de "sistema de referência". Seções para "matar o tempo" ( e por ele ser morta) como palavras cruzadas, "comics", moda etc. ocupam boa parte do jornal.

Ao lado disso, é fácil observar que existem certos artigos que se constituem em estímulos típicos para a tentativa de superar frustrações. Assim, num momento em que a "housewife" esteja em disponibilidade, sem ter o que fazer, ela encontrará alguma coisa com que se ocupar através de estímulos próprios dados pelo emissor, tais como: a maneira mais prática de tirar manchas, gorduras e a melhor maneira de cuidar do corpo.

mundanismo descrito pelas colunas sociais favorece amplos impulsos para a projeção ou rejeição daquele tipo de vida, mas esse assunto será melhor desenvolvido quando nos referirmos aos mundos paralelos.

Os temas, assim tratados, parecem pertencer ao domínio do alvitre.

Galeno de Freitas era rnalista. Foi um dos fundadores do jornal O SOL, trabalhou como repórter no Correio da Manhã, no Jornal do Brasil, na Folha de São Paulo e outros. No Instituto de Estudos Latino-Americanos de Glasgow, Escócia, desenvolveu a pesquisa Reforma Agrária no Peru. Galeno de Freitas faleceu no dia 9 de agosto de 1991. Ocorre que esses dados vêm sendo elaborados pelos "mass media” e estudados por sociólogos da estatura de Vance Packard (Hidden Persuaders) e analistas da argúcia de Roland Barthes ( Mythologies), para ficarmos com os autores mais conhecidos.

A técnica do "depth approach" estudadas por Packard e a teoria da circulação do mito de Roland Barthes, criada a partir dos estudos de linguagem de Ferdinand de Saussure, fornecem elementos para o exame da importância dos órgãos de imprensa bombardeando um público exposto aos seus efeitos. 
Nessa metodologia, assume especial importância a análise dos efeitos da chamada imprensa marrom. Baseada na fórmula "séquiço"-violência esse tipo de imprensa atinge diretamente o proletariado e o lumpen-proletariado, isto é, secção social que Marx considera intrínsecamente revolucionária . Através dessa análise é possível verificar que a imprensa marrom visa primordialmente, a amortecer, e até mesmo extirpar, o potencial revolucionário que o proletariado contém em si.

Através da catarse, a imprensa "séquiço-"violência convoca os leitores a participar de um mundo onírico, em que a realização da ação num cosmos imaginário, provoca a purgação de sua agressividade pela empatia com o herói, geralmente bandido, da ação relatada.

Por meio da mimese a imprensa marrom cria um mundo paralelo ao do leitor, mundo inatingível, mas tornado próximo e considerado obra sua pela leitura do seu jornal. Assim, os relatos de "fait-divers", de acontecimentos sociais e, no mais das vezes, de aventuras amorosas de personalidades das classes superiores, aproximam o leitor desse mundo paralelo e mostram-lhe que a moral de sua classe não difere de maneira marcante da moral de "gente de bem".

No relato de crimes e de violência verifica-se a existência de elementos míticos capazes de criar uma metalinguagem. $O$ mito do herói, elemento catalizador de desejos dos leitores, apresenta uma técnica de construção especial porém desmontável.

O herói-criminoso, por exemplo, nunca pode ter um nome comum . A alcunha coloca-lhe uma auréola de certa grandeza que o diferencia do homem comum e incapaz, na vida cotidiana, de praticar atos heróicos. Assim, jamais o herói-criminoso poderia ser simplesmente João, mas João matador, João estripador, etc. Outros elementos míticos se lhe agregam à personalidade através de narrativas de seus crimes que os tornam ímpares.

A imprensa marrom tem evoluído tecnicamente. $O$ jornal enquanto empresa adapta-se a seu público e se renova quando uma forma de apresentação da notícia se esgota. No jornal O Dia, do Rio de Janeiro, o sociólogo Sergio Lemos verifica a seguinte evolução das manchetes: primeira fase: uso de verbos de ação normal, tais como matar, suicidar, deflorar; segunda fase: uso de verbos de ação marcados pelo exagero e de substantivos fortes, tais como: trucidou, arrazou a vítima, pederasta suicida-se; e uma terceira fase, atual , em que existe um toque de ironia, de criação em termos estritamente jornalísticos, tais como: castrou e jogou os bagos na frigideira.

O mesmo sociólogo mostra que, na maioria das vezes, resulta em engodo o que está sendo anunciado na manchete, pois a narrativa quase nunca corresponde ao dito no título da matéria. Mas isso, observa, faz parte da técnica para vender o jornal.

No domínio do sexo são usadas as mesmas técnicas que relatam a violência, pois, regra geral, os dois elementos básicos da linha editorial marrom vêm combinados na mesma notícia. Especial importância deve-se dar às notícias de escândalo na alta sociedade e no mundo artístico, pois essas informações têm uma meta específica: aproximar os mundos paralelos e unificá-los do ponto de vista moral e emocional já que essa unificação é impossível no tempo econômico.

No campo político o embuste é ainda maior. Pode-se dizer, sem medo de errar, que a imprensa marrom executa uma função essencial no "establishment" ao desviar o público para a discussão de casos menores, fenomênicos e epifenomênicos do sistema.

A luta contra a corrupção e o aumento do custo de vida, produtos imanentes ao regime capitalista, parcelas da dinâmica do sistema, são os elementos fortes da editoria política, de tal modo que a luta política é sempre dirigida contra os efeitos do sistema. 
A cortina de palavras veemente cobre, com densa teia mítica, as causas desses efeitos.

Em outros termos, a imprensa marrom apresenta temas, ou assuntos de conversa,_ao seu público-leitor, evitando a colocação de problemas.

No que diz respeito a reivindicações, elas são sempre dirigidas para pequenas causas, geralmente com fins eleitoreiros: bicas para favelas, buracos na rua, demissão de funcionários subalternos. Enfim, os pequenos dramas do cotidiano são apresentados em conformidade com a técnica que os recobre, obliterando a visão da miséria e a indagação mais profunda das condições que a mantêm. 